\title{
Status and Distribution of Rice Grain Discolouration in Different Ecosystems in Karnataka, India
}

\author{
B. Pampana Gouda ${ }^{1}$, T. Narendrappa ${ }^{1}$, B. S. Chethana ${ }^{2}$ and M. K. Prasanna Kumar ${ }^{2}$ \\ ${ }^{1}$ KrishiVigyan Kendra, Haradanahally Farm, Chamarajanagara-571127, \\ University of Agricultural Science, GKVK, Bengaluru, India \\ ${ }^{2}$ Department of Plant Pathology, University of Agricultural Science, \\ GKVK, Bengaluru, India \\ *Corresponding author
}

\section{A B S T R A C T}

\section{Keywords}

Grain

discolouration,

Survey, Ecosystem,

Disease incidence,

Severity

Article Info

Accepted:

05 April 2020

Available Online:

10 May 2020
A roving survey was conducted during Kharif 2017 and 2018 in five major rice growing ecosystems viz., Kabini and Kaveri, Hilly upland, Thungabhadra and Upper Krishna, Thunga and Bhadra and Coastal belts to know the incidence and severity of grain discolouration in Karnataka. Grain discolouration was recorded in all the samples collected from major rice growing ecosystems. The mean per cent grain discolouration and mean per cent disease index during Kharif 2017 was 12.87 and 12.04 and Kharif 2018 was 13.24 and 12.27 respectively. Both the years, the maximum percent incidence of disease 14.95 and 15.47 and per cent disease index 13.64 and 13.94 respectively was observed in Hilly upland followed by costal belt 14.33 and 15.00 and 13.04 and 13.67 respectively, whereas the least incidence 11.23 and 11.85 and severity 10.22 and 11.03 was noticed in Thunga and Bhadra ecosystem.

\section{Introduction}

India has a long history of rice cultivation. Globally, it stands first in rice area (42.41 million ha) and second in rice production (166.5 million tonnes) (FAO, 2018) after China. It contributes 21.6 per cent to global rice production. Within the country, rice occupies one-quarter of total cropped area, contributes about 40 to 43 per cent of total food grain production and continues to play a vital role in the national food and livelihood security system.

Total area under rice in Karnataka is 1.42 million ha with a production of 3.6 million tones accounting a productivity of 2.62 tonnes per ha. The grain yield per unit area is reducing due to various factors, among which diseases and abiotic stresses are major causes 
for low yield. Rice crop is attacked by more than 76 fungi, bacteria, viruses and mycoplasma like organism causing various diseases in the field. Discolouration has been observed in almost all part of the world wherever rice grown. It was earlier considered to be a minor disease but now gaining more importance due to its severity in tropical rice growing areas.

The disease is distributed throughout Asia, Africa and America. In many regions of India, the early and medium duration rice cultivars grown particularly in wet seasons are generally exposed to high humidity and warm environmental conditions during flowering and post flowering stages which significantly favours the disease incidence.

The fungi reported to be associated with discolouration of grains are Curvularia lunata (highest $35.30 \%$ in Tungabhadra ProjectTBP and Upper Krishna Project-UKP areas of North Eastern Karnataka), Alternaria alternate, Fusarium moniliforme, Bipolaris oryzae, Alternaria padwickii, Pyricularia oryzae, Fusarium graminareum, Nigrospora oryzae, Epicoccum nigrum, Phoma sorghina, Dichotomophthoropsis nymphacearum and Heterosporium echinunulatum etc. (Sumangala and Patil, 2009a).

Rice yield loss due to pests and diseases have been noticed more seriously than ever before. Grain discolouration is considered as "One of the most important threats to rice cultivation" in Karnataka.

The incidence of disease and associated organisms confined to rice crop, it varies with environmental conditions viz., and moisture, temperature, and relative humidity were prevailing in the location. These factors vary with one ecosystem to another ecosystem. In Karnataka, the rice crop is being cultivated in different ecosystem viz., Kabini and Kaveri,
Hilly, Tungabhadra and Krishna, Thunga and Bhadra, and Costal. To know the incidence and severity of grain discolouration in different ecosystem the roving survey has been carried out during Kharif 2017 and Kharif 2018.

\section{Materials and Methods}

Seed samples were collected through roving surveys conducted during Kharif 2017 and Kharif 2018 from farmer's fields of Mysore, Mandya, Chamarajanagara, Kodagu, Uttarkannada, Yadagir, Raichur, Koppal, Bellary, Shivamogga, Chikkamagaluru, Davanagere and Dakshina Kannada districts representing five rice ecosystem.

In each district, one or two taluks, in each taluk, three village and in each village, three plots were surveyed and are listed in the Table 1.Randomy 10 representative panicles from different fields at each location comprising of cultivars were collected, labeled and packed in polyethylene bags and were stored at room temperature $\left(30 \pm 2{ }^{\circ} \mathrm{C}\right)$ for further investigation.

The disease was scored by using 0-9 scale given by IRRI, 2013.

\begin{tabular}{ll} 
Score & \multicolumn{1}{c}{ Description } \\
0 & No symptom of discolouration \\
1 & Less than 1\% discolouration \\
3 & 1 to $5 \%$ discolouration \\
5 & 6 to $25 \%$ discolouration \\
7 & 26 to $50 \%$ discolouration \\
9 & $51 \%$ to $100 \%$ discolouration
\end{tabular}

Per cent disease index was worked out by using the formula

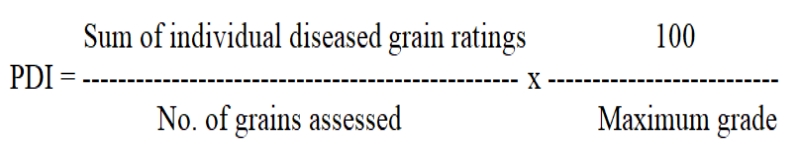


Grain discolouration (\%) was calculated by using the formula,

$$
=\frac{\text { No. of panicles affected }}{\text { Total no. of panicles observed }}
$$

\section{Results and Discussion}

Survey and surveillance studies on grain discolouration helps to identify the "hot spot" of grain discolouration disease in rice from five major rice growing ecosystems of Karnataka. The roving survey was conducted to assess incidence and severity of grain discolouration during Kharif 2017 and 2018 in different taluks of Mysuru, Mandya, Chamarajanagara, Kodagu, Uttara Kannada, Yadagir, Raichur, Koppal, Ballari, Shivamogga, Chikkamagaluru, Davanagere and Dakshina Kannada districts representing major five rice ecosystems viz., Kabini and Kaveri, Hilly upland, Thungabhadra and Upper Krishna, Thunga, Bhadra and Coastal belts of Karnataka. The details of farmer's field surveyed are presented in Table 1 and 2 and were graded as healthy or discoloured grains for further examination.

During Kharif 2017, five major rice growing ecosystems surveyed, the incidence of grain discolouration and severity of disease was prevalent in all the five ecosystems with mean percent disease incidence ranged from 11.23 to 14.95 and mean per cent disease index ranged from 10.22 to 13.64, respectively (Table 1, 2, Fig.1). while the, maximum percent incidence of disease $(14.95 \%)$ and per cent disease index (13.64\%) was observed in hilly upland followed by Costal belt $(14.33 \%)$ and $(13.04 \%)$, whereas the least incidence $(11.23 \%)$ and severity $(10.22 \%)$ was noticed in Thunga and Bhadra ecosystems. The survey data are presented in (Table 1, 2, Fig.1). Among 13 districts surveyed across ecosystems, the incidence and severity of grain discolouration was observed in all districts. The mean per cent disease incidence ranged from 10.29 to 15.70 and mean per cent disease index ranged from 8.64 to14.56. The highest per cent grain discolouration was observed in Kodagu district (15.70\%) followed by Dakshina Kannada district (14.44\%) and least incidence was noticed in Davanagere district (10.29\%).

While the disease severity was maximum in Kodagu district (14.56\%) followed by Dakshina Kannada (13.49\%) and least percent disease index (8.64\%) was observed in Ballari district. The detailed data are presented in (Table 1,).

Out of 69 villages surveyed, highest incidence of disease was in Kankanadi village(17.33\%) in Mangaluru taluk followed by in Mudbidari(16.00\%) in Mangaluru taluk, Hudikeri village in taluk, Bashi village in Sirsi taluk, Madhuvinahalli village in Kollegal taluk, Devarahalli village in Maddur taluk and Basapattana village in Ballari taluk.

The least incidence Mallanayankanakatte village $(8.00 \%)$ in Mandya taluk and Kondajji village in Harihara taluk, whereas highest per cent disease index (16.29\%) in Hudikeri village in Ponnampet and Kankanadi village in Mangaluru taluk followed by (14.81\%) in Mudbidari in Mangaluru taluk, Kumata village in Uttara Kannada, Basapattana village in Ballari taluk and Gorebal village in Sindhanoor taluk. The detailed data are presented in (Table 1)..

During Kharif 2018, The incidence of grain discolouration and severity of disease was prevalent in all five ecosystems with mean percent incidence ranged from 11.85 to 15.47 and mean per cent disease index ranged from 11.03 to 13.94 , respectively (Table 1, 2, Fig.2). The highest percent incidence $(15.47 \%)$ and per cent disease index (13.94\%) 
was observed in Hilly upland followed by Costal belt $(15.00 \%)$ and $(13.67 \%)$, whereas the least incidence (11.85\%) and severity (11.03) was noticed in Thunga and Bhadra ecosystem. The data are presented in (Table 1, 2, Fig.2).

Totally thirteen districts surveyed, the incidence and severity of grain discolouration was observed in all districts. The mean per cent disease incidence ranged from 10.95 to 16.14 and mean per cent disease index ranged from 10.31 to14.56. The highest per cent discolouration (16.14\%) was observed in Kodagu district followed by Dakshina Kannada district (15.23\%) and least incidence was noticed in Davanagere district (10.95\%).

While the disease severity was maximum in Dakshina Kannada district (14.56\%) followed by Kodagu district (14.31\%) and least percent disease index $(10.31 \%)$ was observed in Davanagere district and data are presented in (Table 1, ).

Out of 69 villages surveyed, highest incidence of disease $(17.77 \%)$ was in Kankanadi village in Mangaluru taluk and Srimangala village in Ponnampet taluk followed by $(16.00 \%)$ in Bashi village in Sirsi taluk, Gowdahalli village in Kollegal taluk, Kumata village in Uttara Kannada taluk, Suttur village in Mysuru taluk and Udupi village in Udupi taluk and least incidence in Kondajji village in Harihara taluk and highest per cent disease index $(15.55 \%)$ in Udupi village in Udupi taluk followed by $(14.81 \%)$ in Kundapur village in Udupi taluk, Kumata village in Uttara Kannada, Bashi village in Sirsi taluk and Guttiganur village in Ballari taluk and least percent disease index (10,31\%) was observed in Agatahalli village in Pandavapur taluk and Avaraglla village in Davanagere taluk, and data are presented in (Table 1). The results from table 3 indicated that, grain discolouration of rice was prevalent in all five ecosystems surveyed which include 207 fields form 69 villages of 23 taluks from fifteen districts of Karnataka. Mean per cent grain discolouration of 12.87 during kharif 2017 and 13.24 during Kharif 2018 and per cent disease index of 12.04 during Kharif2017 and 12.27 during Kharif 2018 (Table 2, Fig.1, Fig.2).

These survey results are corroborate with previous reports from Saifulla (1997) who reported that grain discolouration of rice was maximum in hilly region varied from 5 to 50 per cent followed by costal region which varied from 0 to 50 per cent, whereas in plain region varied from 0 to 5 per cent during summer and 0 to 25 per cent in Kharif. During 1989 and1990, the incidence of rice grain discolouration was assessed in Bilaspur, Chamba, Hamirpur, Kangra, Kullu, Mandi, Sirmour, Solan and Una districts of Himachal Pradesh. Maximum grain discolouration was recorded at Rahlu in Kanga district $(88.12 \%)$ and least was in Una district (7.60\%) (Sharma and Vaid, 1990).

Rice grain discolouration was found to vary with variety and Negi and Das (2003) reported that 18 varieties, Narendra 80 and 97 experienced maximum grain discolouration $(54.7 \%)$ and were followed by Narendra 359 (47.4\%), Manhar (46.6\%), Basmati 385 (45.4\%), Saket 4 (45.3\%), Phat Dhan 11 (41.2\%), Phat Dhan 16 (40.3\%), Phat Dhan 12 (39.4\%), Improved Sarbati (39.3\%), Improved Indrasan (36.8\%), Pant Sugandha Dhan 15 (35.8\%), Jaya (35.7\%), Basmati 386 (33.9\%), Phat Dhan 10 (31.2\%), Taraori Basmati (30.7\%) and Sarjoo 52 (29.2\%), whereas minimum discolouration was observed in Pusa 44 (27.5\%). Imran Arshad et al., (2009) reported that the grain discolouration disease of rice is becoming a serious threat to rice cultivation during Kharif season as compared to summer season in hilly area of Pakistan. 
Table.1 Incidence of grain discolouration of rice in different ecosystems in Karnataka during Kharif 2017and Kharif 2018

\begin{tabular}{|c|c|c|c|c|c|c|c|c|c|c|c|c|c|}
\hline \multirow[b]{2}{*}{ Ecosystems } & & \multirow[b]{2}{*}{ Taluks } & \multirow[b]{2}{*}{ Villages } & \multirow[b]{2}{*}{$\begin{array}{l}\text { No of } \\
\text { fields }\end{array}$} & \multirow[b]{2}{*}{$\begin{array}{c}\text { Major } \\
\text { varieties }\end{array}$} & \multicolumn{4}{|c|}{2017} & \multicolumn{4}{|c|}{2018} \\
\hline & Districts & & & & & $\begin{array}{c}\text { Diseases } \\
\text { Incidence } \\
(\%)\end{array}$ & $\begin{array}{l}\text { Per cent } \\
\text { disease } \\
\text { index } \\
\text { (PDI) }\end{array}$ & $\begin{array}{c}\text { Mean } \\
\text { Diseases } \\
\text { Incidence } \\
(\%) \text { of } \\
\text { ecosystem }\end{array}$ & $\begin{array}{l}\text { Mean } \\
\text { per cent } \\
\text { disease } \\
\text { index } \\
\text { (PDI) }\end{array}$ & $\begin{array}{c}\text { Diseases } \\
\text { Incidence } \\
(\%)\end{array}$ & $\begin{array}{c}\text { Per cent } \\
\text { disease } \\
\text { index } \\
\text { (PDI) }\end{array}$ & $\begin{array}{c}\text { Mean } \\
\text { Diseases } \\
\text { Incidence } \\
(\%)\end{array}$ & $\begin{array}{l}\text { Mean } \\
\text { per cent } \\
\text { disease } \\
\text { index } \\
\text { (PDI) }\end{array}$ \\
\hline \multirow{21}{*}{$\begin{array}{l}\text { Irrigated } \\
\text { Kabini and } \\
\text { Kaveri }\end{array}$} & \multirow{6}{*}{$\begin{array}{l}\text { Chamaraj } \\
\text { angar }\end{array}$} & \multirow[t]{3}{*}{ Yalandur } & Y.K.Mole & 3 & \multirow{3}{*}{$\begin{array}{l}\text { IR-64 } \\
\text { MTU-1010 } \\
\text { Gangavati } \\
\text { sona } \\
\text { Aman } \\
\text { KRH-4 }\end{array}$} & 13.33 & 11.85 & \multirow{16}{*}{12.16} & \multirow{16}{*}{11.59} & 10.66 & 11.11 & \multirow{16}{*}{12.22} & \multirow{16}{*}{11.27} \\
\hline & & & Yariyuru & 3 & & 12.00 & 11.11 & & & 15.55 & 13.33 & & \\
\hline & & & Maddur & 3 & & 09.33 & 10.37 & & & 08.88 & 08.15 & & \\
\hline & & \multirow[t]{3}{*}{ Kollegal } & Madhuvanahalli & 3 & \multirow{3}{*}{$\begin{array}{l}\text { IR-64 } \\
\text { MTU- } \\
1001 \\
\text { Aman }\end{array}$} & 16.00 & 12.59 & & & 13.33 & 12.59 & & \\
\hline & & & Gowdalli & 3 & & 13.33 & 14.07 & & & 16.00 & 14.07 & & \\
\hline & & & Uttamballi & 3 & & 10.66 & 11.11 & & & 11.10 & 08.89 & & \\
\hline & & & & 12.44 & 11.85 & & & 12.58 & 11.35 & & \\
\hline & \multirow{9}{*}{ Mandya } & \multirow{3}{*}{ Mandya } & \multirow{3}{*}{\multicolumn{2}{|c|}{\begin{tabular}{l|l|l|}
\multicolumn{3}{c}{ District average } \\
& 3 & Jaya \\
& 3 & IR-64 \\
atte & 3 & Thanu \\
& & BR-2655 \\
& & KRH-4 \\
\end{tabular}}} & \multirow{3}{*}{$\begin{array}{l}\text { Jaya } \\
\text { IR-64 } \\
\text { Thanu } \\
\text { BR-2655 } \\
\text { KRH-4 }\end{array}$} & 12.00 & 12.59 & & & 11.10 & 08.89 & & \\
\hline & & & & & & 10.66 & 9.63 & & & 13.33 & 12.59 & & \\
\hline & & & & & & 08.00 & 8.89 & & & 10.66 & 11.11 & & \\
\hline & & & Devarahalli & 3 & BR-2655 & 16.00 & 14.81 & & & 13.33 & 11.85 & & \\
\hline & & Maddur & Doddaarasinakere & 3 & Jayakrishna & 13.33 & 11.85 & & & 08.88 & 10.37 & & \\
\hline & & & Alemanegate & 3 & & 12.66 & 12.59 & & & 10.66 & 08.89 & & \\
\hline & & Pandavapura & Pandavapur & 3 & MTU1010 & 10.66 & 11.11 & & & 15.55 & 13.33 & & \\
\hline & & & Agatahalli & 3 & BR-2655 & 08.00 & 07.40 & & & 11.11 & 07.40 & & \\
\hline & & & Alphahalli & 3 & Aman & 09.33 & 08.89 & & & 08.88 & 11.11 & & \\
\hline & & & Distr & average & & 11.18 & 10.86 & & & 11.50 & 10.61 & & \\
\hline & Mysore & & Suttur & 3 & Jyoti & 14.66 & 13.33 & & & 16.00 & 14.07 & & \\
\hline & & Mysore & Basavanapur & 3 & $\begin{array}{l}\text { Gangavati } \\
\text { sona } \\
\text { MTU-1010 }\end{array}$ & 13.33 & 12.59 & & & 11.10 & 12.59 & & \\
\hline & & & Horalawadi & 3 & & 10.66 & 10.37 & & & 10.66 & 08.89 & & \\
\hline & & & Dis & ct avera & & 12.88 & 12.07 & & & 12.58 & 11.85 & & \\
\hline
\end{tabular}




\begin{tabular}{|c|c|c|c|c|c|c|c|c|c|c|c|c|c|}
\hline \multirow{8}{*}{ Hilly upland } & \multirow[t]{3}{*}{ Kodagu } & \multirow{3}{*}{ Ponnampet } & Hudikeri & 3 & \multirow{3}{*}{\begin{tabular}{|l|} 
Jaya \\
Sona \\
massuri \\
Local
\end{tabular}} & 16.00 & 16.29 & \multirow{8}{*}{14.95} & \multirow{8}{*}{13.64} & 16.00 & 16.29 & \multirow{8}{*}{15.47} & \multirow{8}{*}{13.94} \\
\hline & & & Srimangala & 3 & & 13.33 & 14.7 & & & 17.77 & 11.85 & & \\
\hline & & & Balele & 3 & & 17.77 & 13.33 & & & 14.66 & 14.81 & & \\
\hline & \multirow{5}{*}{$\begin{array}{l}\text { Uttara } \\
\text { Kannada }\end{array}$} & & \multicolumn{3}{|c|}{ District average } & 15.70 & 14.56 & & & 16.14 & 14.31 & & \\
\hline & & \multirow{3}{*}{ Sirsi } & Yedurbail & 3 & \multirow{4}{*}{$\begin{array}{l}\text { Jaya } \\
\text { KMP105 } \\
\text { Abhilash } \\
\text { Hemavati } \\
\text { ge }\end{array}$} & 10.66 & 08.89 & & & 10.66 & 13.33 & & \\
\hline & & & Bashi & 3 & & 16.00 & 14.81 & & & 16.00 & 14.81 & & \\
\hline & & & Gudnapur & 3 & & 13.33 & 12.59 & & & 17.77 & 12.59 & & \\
\hline & & & & ict & & 13.33 & 12.09 & & & 14.81 & 13.57 & & \\
\hline \multirow{19}{*}{$\begin{array}{l}\text { Irrigated } \\
\text { ecosystem of } \\
\text { TBP and } \\
\text { UKP }\end{array}$} & \multirow[t]{4}{*}{ Raichur } & \multirow[t]{4}{*}{ Sindhanoor } & Gorebal & 3 & \multirow{3}{*}{$\begin{array}{l}\text { BPT-5204 } \\
\text { RNR-15048 } \\
\text { Gangavati } \\
\text { Sona } \\
\text { Nellur Sona } \\
\text { Kaveri Sona } \\
\end{array}$} & 13.33 & 14.81 & \multirow{19}{*}{11.85} & \multirow{19}{*}{11.03} & 11.10 & 11.85 & \multirow{19}{*}{12.62} & \multirow{19}{*}{12.36} \\
\hline & & & Sindhanoor & 3 & & 12.00 & 11.85 & & & 10.86 & 11.11 & & \\
\hline & & & Javalagera & 3 & & 11.33 & 09.63 & & & 13.33 & 10.89 & & \\
\hline & & & \multicolumn{3}{|c|}{ District average } & 12.22 & 12.09 & & & 11.76 & 11.28 & & \\
\hline & \multirow[t]{4}{*}{ Koppal } & \multirow{4}{*}{ Gangavati } & Basapattana & 3 & \multirow{4}{*}{$\begin{array}{l}\text { BPT-5204 } \\
\text { Gangavati } \\
\text { Sona } \\
\text { Nellur Sona } \\
\text { RNR-15048 } \\
\text { Kaveri Sona }\end{array}$} & 16.00 & 14.81 & & & 15.00 & 13.33 & & \\
\hline & & & Heruru & 3 & & 14.66 & 13.33 & & & 11.11 & 10.89 & & \\
\hline & & & Anegundi & 3 & & 12.59 & 11.85 & & & 13.33 & 12.59 & & \\
\hline & & & \multicolumn{2}{|c|}{ District average } & & 14.41 & 13.33 & & & 13.14 & 12.27 & & \\
\hline & \multirow{10}{*}{ Bellari } & Siruguppa & Siruguppa & 3 & \multirow{3}{*}{$\begin{array}{l}\text { BPT-5204 } \\
\text { Gangavati } \\
\text { Sona } \\
\text { Nellur Sona } \\
\text { Kaveri Sona }\end{array}$} & 10.66 & 09.63 & & & 11.11 & 08.89 & & \\
\hline & & & B.M.Sugur & 3 & & 12.00 & 12.59 & & & 12.00 & 12.59 & & \\
\hline & & & Balakundi & 3 & & 13.33 & 14.81 & & & 13.33 & 11.11 & & \\
\hline & & \multirow[t]{3}{*}{ Hospete } & Kamalapur & 3 & \multirow{3}{*}{$\begin{array}{l}\text { BPT-5204 } \\
\text { RNR-15048 } \\
\text { Gangavati } \\
\text { Sona } \\
\text { Nellur Sona } \\
\text { Kaveri Sona }\end{array}$} & 9.33 & 08.89 & & & 09.33 & 08.89 & & \\
\hline & & & Kampli & 3 & & 10.66 & 09.63 & & & 10.66 & 09.63 & & \\
\hline & & & Ramasagara & 3 & & 13.33 & 12.59 & & & 11.10 & 08.89 & & \\
\hline & & Bellari & Emmignur & 3 & BPT-5204 & 12.00 & 11.85 & & & 12.00 & 11.85 & & \\
\hline & & & Guttiganur & 3 & Gangavati & 13.33 & 14.81 & & & 15.55 & 14.81 & & \\
\hline & & & Kottal & 3 & $\begin{array}{l}\text { Sona } \\
\text { Nellur Sona } \\
\text { Kaveri Sona }\end{array}$ & 12.66 & 12.59 & & & 08.88 & 07.40 & & \\
\hline & & & & ict & & 11.88 & 11.93 & & & 11.55 & 10.45 & & \\
\hline & Yadgiri & Shahpur & Hothpete & 3 & RNR-15048 & 10.66 & 11.85 & & & 09.33 & 11.85 & & \\
\hline
\end{tabular}




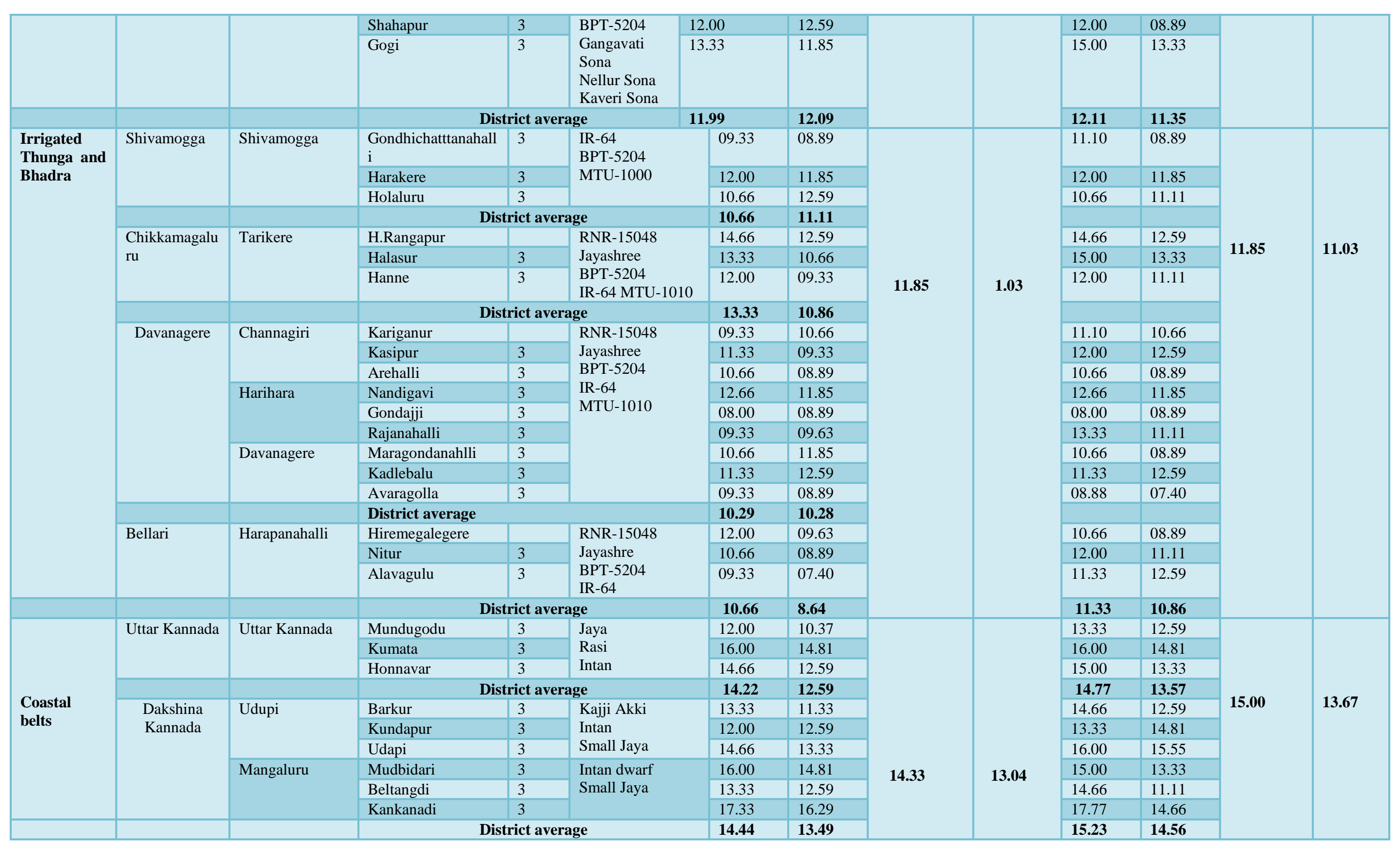


Table.2 Incidence of grain discolouration of rice in different ecosystems in Karnataka during Kharif 2017 and Kharif 2018

\begin{tabular}{|c|c|c|c|c|c|c|c|c|c|}
\hline & & & & & & \multicolumn{2}{|c|}{2017} & \multicolumn{2}{|c|}{2018} \\
\hline Ecosystems & $\begin{array}{l}\text { No of } \\
\text { districts } \\
\text { covered }\end{array}$ & $\begin{array}{l}\text { No of } \\
\text { taluks } \\
\text { covered }\end{array}$ & $\begin{array}{l}\text { No of } \\
\text { villages } \\
\text { covered }\end{array}$ & $\begin{array}{l}\text { No of } \\
\text { fields } \\
\text { covered }\end{array}$ & Major varieties & $\begin{array}{l}\text { Diseases } \\
\text { Incidence } \\
(\%)\end{array}$ & $\begin{array}{l}\text { Per cent } \\
\text { disease } \\
\text { index } \\
\text { (PDI) }\end{array}$ & $\begin{array}{l}\text { Diseases } \\
\text { Incidence } \\
(\%)\end{array}$ & $\begin{array}{l}\text { Per cent } \\
\text { disease } \\
\text { index } \\
\text { (PDI) }\end{array}$ \\
\hline $\begin{array}{l}\text { Irrigated } \\
\text { Kabini and } \\
\text { Kaveri }\end{array}$ & 3 & 6 & 18 & 54 & $\begin{array}{l}\text { IR-64,MTU- } \\
\text { 1010,Gangavati } \\
\text { sona,Aman,KRH- } \\
\text { 4,Thanu } \\
\text { BR-2655,KRH-4 }\end{array}$ & 12.16 & 11.59 & 12.22 & 11.27 \\
\hline $\begin{array}{l}\text { Hilly } \\
\text { upland }\end{array}$ & 2 & 2 & 6 & 18 & $\begin{array}{l}\text { Jaya,Sona } \\
\text { massuri,Local } \\
\text { Jaya,KMP105,Abhilash } \\
\text { Hemavati }\end{array}$ & 14.95 & 13.64 & 15.47 & 13.94 \\
\hline $\begin{array}{l}\text { Irrigated } \\
\text { ecosystems } \\
\text { of TBP and } \\
\text { UKP } \\
\text { command }\end{array}$ & 4 & 6 & 18 & 54 & $\begin{array}{l}\text { BPT-5204,RNR-15048 } \\
\text { Gangavati Sona,Nellur } \\
\text { Sona } \\
\text { Kaveri Sona }\end{array}$ & 12.62 & 12.36 & 12.22 & 11.35 \\
\hline $\begin{array}{l}\text { Irrigated } \\
\text { Thunga } \\
\text { and } \\
\text { Bhadra }\end{array}$ & 4 & 6 & 18 & 54 & $\begin{array}{l}\text { RNR-15048,Jayashree } \\
\text { BPT-5204,IR-64,MTU- } \\
1010\end{array}$ & 11.23 & 10.22 & 11.85 & 11.03 \\
\hline $\begin{array}{l}\text { Coastal } \\
\text { belts }\end{array}$ & 2 & 3 & 9 & 27 & $\begin{array}{l}\text { Jaya,KMP105,Abhilash } \\
\text { Hemavati }\end{array}$ & 14.33 & 13.04 & 15.00 & 13.67 \\
\hline & 15 & 23 & 69 & 207 & Mean Average & 12.87 & 12.04 & 13.24 & 12.27 \\
\hline
\end{tabular}




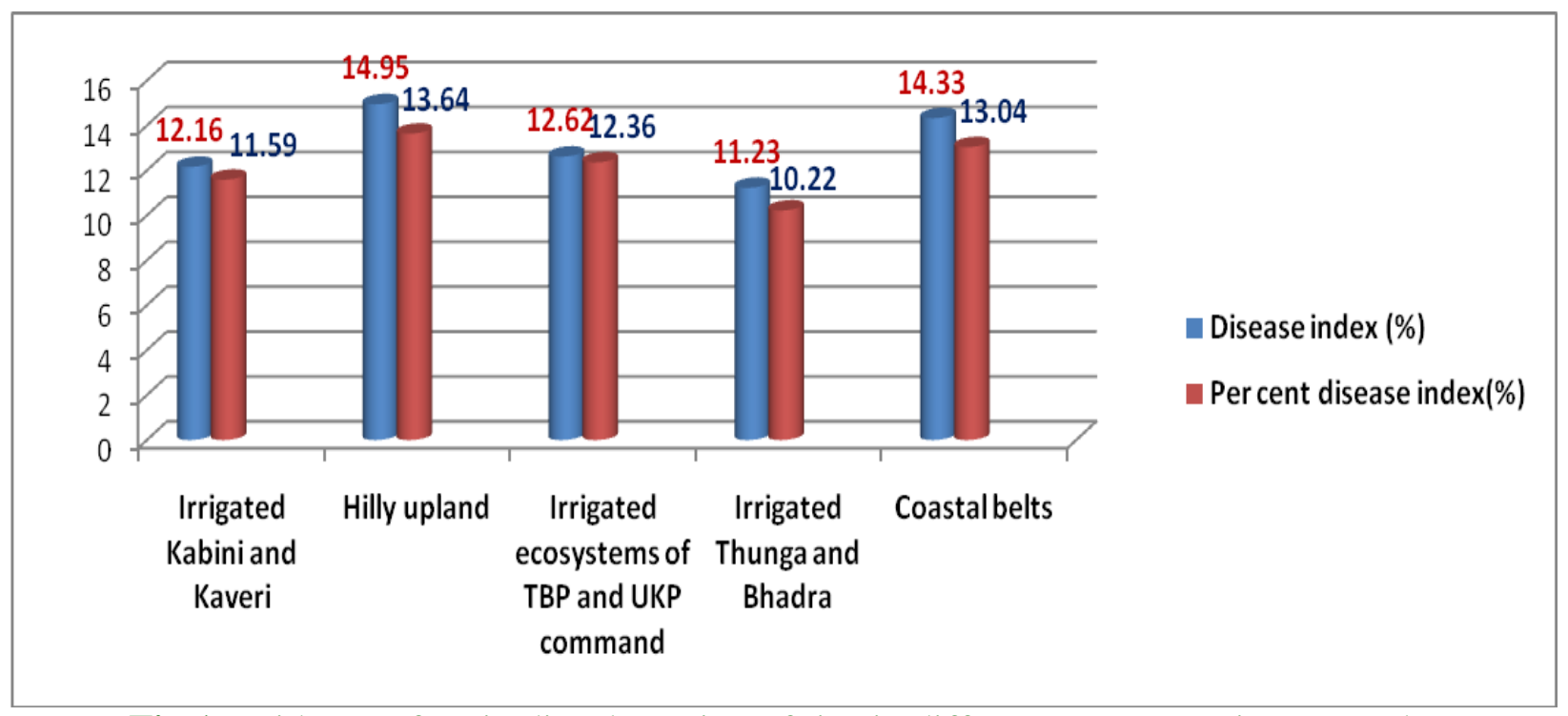

Fig.1 Incidence of grain discolouration of rice in different ecosystem in Karnataka during Kharif 2017

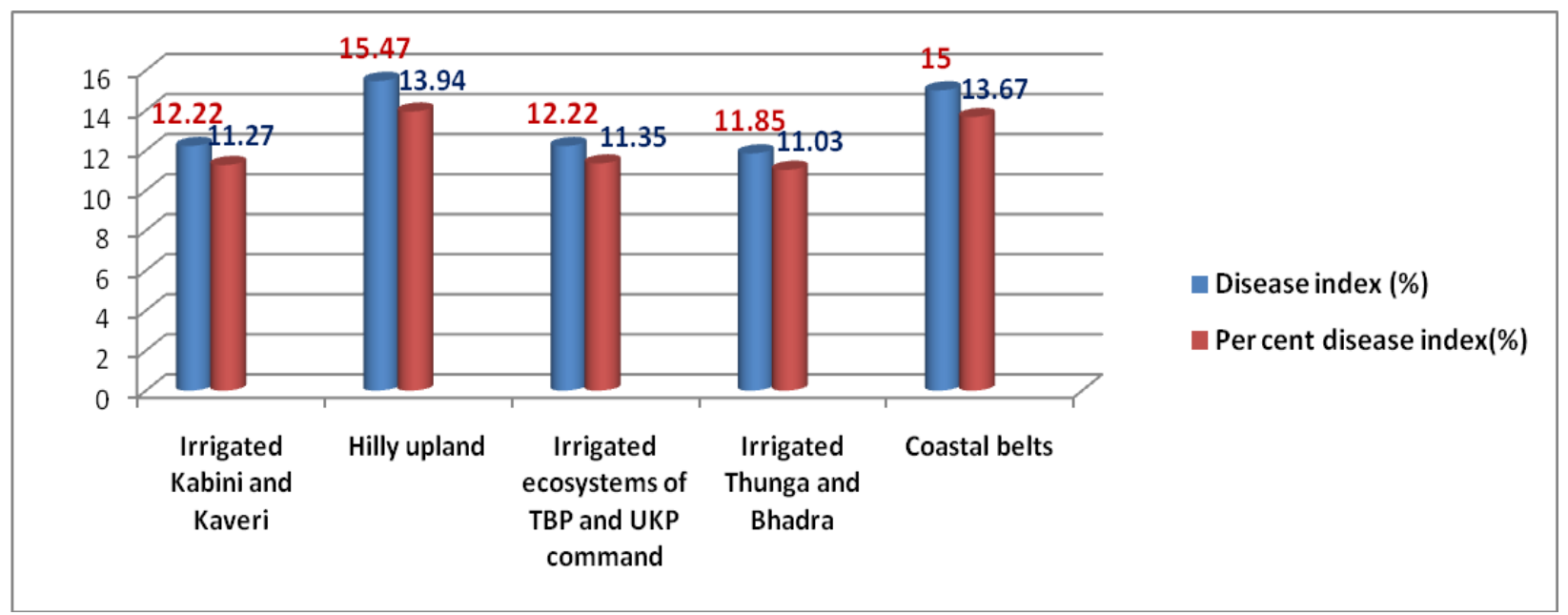

Fig.2 Incidence of grain discolouration of rice in different ecosystem in Karnataka during Kharif 2018

Total 287 seed samples consisting of 20 cultivars collected from major rice growing parts of Tamil Nadu and were used for analysis of health status. Among them, the per cent disease incidence ranged from 1.39 to 58.89 per cent. (Gopalakrishnan et al., 2010) and Sumangala et al., (2010) reported mean per cent incidence $10.34,8.69$ and 11.27 and mean per cent index 9.05, 8.39 and 10.70 in Raichur, Yadgir and Koppal, plain regions of North Eastern districts of Karnataka, respectively. The rice grain discolouration samples were collected from four districts of Andhra Pradesh. The percentage of discoloured grains from West Godavari district samples was ranged from 21.91 to 27.32 on weight basis and from 22.74 to 28.88 on grain number based analysis.

The corresponding percentages were; Krishna district - 23.02 to 28.62 and 24.34 to $30.35 \%$, Guntur district -22.58 to 28.76 and 24.57 to 30.46 , and Nellore district - 22.88 to $28.74 \%$ and 25.05 to $30.81 \%$ (Divya, 2015). 


\section{Acknowledgement}

Facilities were provided by Department of Plant Pathology, GKVK, University of Agricultural Sciences, Bengaluru and College of Agriculture, V.C.Farm, Mandya are acknowledged.

\section{References}

Divya, M. (2015). Effect of grain discoloration complex disease on rice seed quality and its management, $M$. Sc. Thesis, Acharya N.G. rangaAgril. Univ., Hyderabad, India.pp: 76-78.

FAO., (2018). Global paddy production and area. Food and Agriculture Organization of United Nation., Volume XXI, Issue No.1. pp.1.

Goplakrishnan, et al., (2010). Survey of seedborne fungi associated with rice seeds in Tamil Nadu, India. Libyan Agri. Res. CenterJ. Int.,5: 307-309.

Imran Arshad, et al., (2009). Grain discolouration disease complex: A new threat for rice crop and its management. Pakistan J. Phytopath., 21: 31-36.

IRRI., 2013, Standard Evaluation System for Rice. IRRI, Manila, Philippines., pp.56.

Negi, H. and Das, B. ( 2003). Screening of rice varieties against seed discoloration. Indian Phytopath.,56: 460-461.

Saifulla, M.,(1997). Cause and consequence of rice grain discoloration rice. $M . S c$. Thesis, Univ. Mys. Karnataka, India. pp :76-77.

Sharma, O. P.and Vaid, A.(1990). Status and distribution of grain discolouration disease of rice in Himachal Pradesh. Indian Phytopath.,43: 47.

Sumangala, K.and Patil, M.B.(2009a). Panchagavya- An organic weapon against Plant Pathogens. J. Pl. Dis. Sci., 4: 132-135.

Sumangala, K., et al., (2010). Status and distribution of rice grain discolouration in north eastern Karnataka. Karnataka J. Agric. Sci., 23: 804-805.

\section{How to cite this article:}

Pampana Gouda. B., T. Narendrappa, B. S. Chethana and Prasanna Kumar. M. K. 2020. Status and Distribution of Rice Grain Discolouration in Different Ecosystems in Karnataka, India. Int.J.Curr.Microbiol.App.Sci. 9(05): 796-805. doi: https://doi.org/10.20546/ijcmas.2020.905.088 